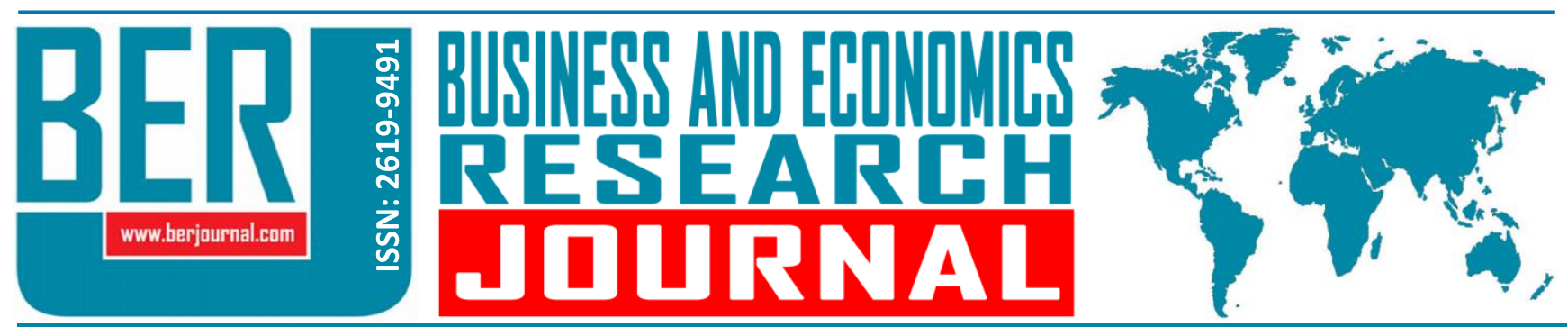

Business and Economics Research Journal Vol. 10, No. 2, 2019, pp. 391-404 doi: 10.20409/berj.2019.175

\title{
Comparison of Country Ratings of Credit Rating Agencies with MOORA Method
}

\section{Elif Guneren Genc ${ }^{\mathrm{a}}$, Ozlem Deniz Basar ${ }^{\mathrm{b}}$}

Abstract: The three main credit rating agencies, Standard and Poor's, Moody's and Fitch, use a combination of economic, social and political factors to determine the capacity and current and future debt obligation of countries. This study contributes to literature in two ways. The first one is comparison of results obtained by rating countries on various macroeconomic variables using credit scores given by the three main credit rating agencies and using the MOORA method. The second one is the determination of how optimistic or pessimistic country-based results the three main credit rating agencies yield according to their estimates by macroeconomic variables. Among the three rating agencies, Moody's make the most optimistic estimates in terms of its rating of countries. Moody's is followed by Standard and Poor's, and the credit rating agencies that make the most pessimistic estimates is observed to be Fitch.
Keywords: MOORA, Sovereign Credit Rating, Rating Agencies

JEL: C10, G24, 057

$\begin{array}{ll}\text { Received } & : 26 \text { November } 2018 \\ \text { Revised } & : 29 \text { January } 2019 \\ \text { Accepted } & : 06 \text { February } 2019\end{array}$

Type : Research

\section{Introduction}

Sovereign credit rating is a rating assigned by rating agencies on financial and economic obligations of a specific country. The determination of the position of a country in international markets plays an important role in the country's access to debt markets and in the formation of suitable conditions for this access. There are three main credit rating agencies (CRA) which assign sovereign ratings to countries. These are Standard and Poor's Rating Services (S\&P), Moody's Corporation (Moody's) and Fitch Ratings (Fitch). Credit rating agencies (CRA) compose a rating as a result of a number of combinations obtained by varying the economic, social and political variables of countries.

CRAs are important agencies that operate within credit markets and provide information for the functioning of financial system. Through their ratings, they establish a ground for financial agreement, influence investment decisions, provide financial regulations, and also take a critical position in financial crises (Baghai \& Becker, 2018). At the present time, the effect of macroeconomic variables on sovereign ratings is a significant knowledge for politicians, foreign investors, financial authorities and academicians. With the financial crisis started in 2007 and escalated in 2008, works of credit rating agencies have been taken into consideration not only by financial markets but also by academicians again (Arezki, Candelon, \& Amadou, 2011; Baum, Checherita-Westphal, \& Rother, 2012). Over time, this led to a debate on the reliability of sovereign ratings by CRAs and especially after the crisis, it was found out that CRAs assigned inaccurate

a Assoc. Prof., PhD., Istanbul Commerce University, Department of Banking and Finance, Istanbul, Turkiye, elifg@ticaret.edu.tr (ORCID ID: 0000-0001-5439-914X)

b Assoc. Prof., PhD., Istanbul Commerce University, Department of Statistics, Istanbul, Turkiye, odeniz@ticaret.edu.tr (ORCID ID: 0000-0002-9430-8975) 
ratings to some countries. S\&P, Moody's and Fitch ratings, determined by analyzing economic, social and political variables, are significant criteria used in comparing countries and assessing whether they are feasible for economic investments. However, it may cause variations in country rankings to use different macroeconomic variables in the comparison of economic structures. This study contributes to literature in two ways. The first one is comparison of results obtained by rating countries on various macroeconomic variables using credit scores given by the three main credit rating agencies and using the MOORA method. The second one is the determination of how optimistic or pessimistic country-based results the three main credit rating agencies yield according to their estimates by macroeconomic variables.

\section{Literature}

The credit rating for a country given by credit rating agencies corresponds to the economic, financial and political performance of a country and its capacity to repay its credits. Information about a country's capacity to fulfil its financial liabilities gives international investors the possibility to diversify among various countries and various investment opportunities. It is possible for credit rating agencies to create rating models for countries according to a large number of variables as well as models in which only relevant variables are engaged based on different periods and circumstances in different countries.

In 2006, Mellios and Paget-Blanc intended to define the common factors that affect credit ratings in order to determine the variables in a credit rating assigned by the three major CRAs (S\&P, Moody's, and Fitch). The results showed that sovereign ratings are mostly affected by income per capita, government income, changes in real exchange rates, inflation rate, and Transparency International's Corruption Perceptions Index (Mellios \& Paget-Blanc, 2006). It is intended to find out the difference between credit rating agencies in credit quality assessment with ordered probit and hazard model regressions, using credit rating data by the three major CRAs (S\&P, Moody's, and Fitch) for 129 countries in years 1990-2006. First of all, although CRAs mostly disagree with each other, this variation is usually limited only to one or two points. It was found out that, on lower rating levels, rating stability is lower for S\&P compared to Fitch or Moody's and six variables are the common determinants for the three agencies' rating of credit quality (Hill, Brooks, \& Faff, 2010).

In their study in 2013, Bodenstedt, Rösch, \& Scheule questioned the accuracy of CRA ratings in relation to the global financial crisis in 2007. To that end, they studied the performance of Moody's and observed poor rating quality especially during and after the financial crisis and also identified the macroeconomic factors specific to time periods that explain these variations in the performance of Moody's (Bodenstedt, Rösch, \& Scheule, 2013). Emphasizing the importance of macroeconomic variables in their 2013 study, Bozic\& Magazinno evaluated the sovereign ratings for 139 countries by the three main CRA in years 1975-2010 using unbalanced panel method. They showed that GNP per capita, inflation rate, unemployment rate, fiscal balance, government debt, and default history significantly affect ratings while GNP growth and current accounts deficit are less related (Bozic \& Magazzino, 2013).

Erdem\&Varli found out that the most important macroeconomic factors behind credit ratings of developing markets by S\&P are budget balance/GDP, GDP per capita, governance indicators, and reserves/GDP (Erdem \& Varli, 2014). Analyzing 82 countries in years 2004-2011 with multiple linear regression where the variable dependent on macroeconomic variables is the credit ratings assigned by the three main CRAs to each country, Martin-Garcia, Tellez-Valle, \& Martin-Marin observed that the weight of variables has significantly changed from the model structure in the early 1990 s and early 2000 s to the model structure as of 2007 especially after the start of the economic and financial crisis (Martin-Garcia, Tellez-Valle, \& Martin-Marin, 2014). In their 2014 study, Abad and Robles analyzed the effects of credit ratings of six different credit rating agencies on systematic and ideological risks studying Spanish stocks from 1988 to 2010. They identified a significant effect on the risks, of any rating announcement (upgrades/downgrades, reviews, and outlook reports) by the rating agencies, whether positive or negative (Abad \& Robles, 2014). Kabadayi and Celik (2015) examined the effect of macroeconomic and political variables on sovereign ratings of countries using the panel probit model. The conclusion was that credit rating agencies consider the political and economic framework when rating developing countries (Kabadayi \& Celik, 2015). In his 2015 study, 
Freitag assessed the capacity to repay debt of European countries based on ratings by credit rating agencies using probit model and concluded that credit rating agencies take macroeconomic factors into consideration, however there is inconsistency with regards to upgrades and downgrades in ratings (Freitag, 2015). Hamdi, Herwany, \& Tanzil (2015) intended to see if the macroeconomic variables they selected have any effect on ratings by Moody's and Fitch, to compare the ratings given by CRA, and to find out whether sovereign ratings influence return on stock indices. They found out that especially GDP per capita, inflation and reserves significantly affect sovereign ratings by Moody's and Fitch, that Fitch is better than Moody's in terms of evaluation, and that sovereign rating has a positive effect on index return in developing markets (Hamdi, Herwany, \& Tanzil, 2015).

Researchers usually analyze the effects of macroeconomic and political variables on ratings using probit and logit panel data analysis methods. In their 2016 study, Karminsky and Khromova created a reliable bank rating model based on publicly available data using probit model in order to estimate credit rating of banks assigned by the three main CRA. Their study showed that including macroeconomic variables and regional impact in the model increased the model's explanatory power and estimation performance. They also found out that S\&P ratings have a conservative nature and Moody's ratings show better performance compared to other rating agencies (Karminsky \& Khromova, 2016). Ozturk's study in 2016 which analyzed the relationship between sovereign credit ratings by CRAs and countries' governance variables showed that six different international governance variables are positively related with higher credit ratings and also credit ratings significantly respond to developments in these indicators (Ozturk, 2016). In his study, loannous (2018) stated that credit rating agencies not only present an opinion when determining ratings of countries, but also influence macroeconomic dynamics of countries. To this end, he selected two countries as a representative of the Eurozone. Using stock flow consistent model, he then attempted to find out how dynamics of financial markets and limitations on fiscal policies, as well as activity of credit ratings affect each other. Thus, he ascertained that, in case of recession in countries' economy, credit ratings are downgraded and as a result, financial troubles of the country worsen and on-going recession deepens even more with austerity policy (Ioannous, 2018). In their study which examined the effectiveness of changes in sovereign credit ratings on the cost of borrowing of EU countries, Kunovac and Ravnik (2018) showed that sovereign credit ratings are only of a limited economic importance for the cost of borrowing of countries. For the analysis, they used a panel composed of daily data over the period from January 2007 to September 2015 for 23 EU countries. They concluded that CRAs do not provide financial markets any new or important information in addition to the information already present in fundamental principles, hence cost of borrowing for a country can only be lowered by improving the macroeconomic and financial foundation of the country (Kunovac \& Ravnik, 2018).

\section{Methodology - MOORA (Multi-Objective Optimization on Basis of Ratio Analysis)}

Multi-criteria decision making methods are widely used in literature by decision makers for subjective evaluation of performance criteria with mathematical tools (Mardani et al., 2015: 516), due to its simple mathematical application. Analytic hierarchy process (AHP), technique for order preference by similarity to ideal solution (TOPSIS), VIseKriterijumska Optimizacija I Kompromisno Resenje (VIKOR), elimination and choice expressing reality (ELECTRE) and the preference ranking organization method for enrichment evaluation (PROMETHEE) stand out as the most common multi-criteria decision-making methods. Moreover, it is known that multi-objective optimization on basis of ratio analysis (MOORA) is also used in recent years beside the above methods.

First used by Brauers and Zavadskas (2006) (Brauers \& Zavadskas, 2006), MOORA method is one of the multi-criteria decision making methods, that emerged as a frequently used method in literature in this times in which rankings in finance, healthcare, engineering and education are of great importance. 
Comparison of Country Ratings of Credit Rating Agencies with MOORA Method

Table 1. Comparison of Multi-Criteria Decision Making Methods

\begin{tabular}{|l|l|l|l|}
\hline MODM & Mathematical Calculations & Simplicity & Stability \\
\hline MOORA & Minimum & Very simple & Good \\
AHP & Maximum & Very critical & Poor \\
TOPSIS & Moderate & Moderately critical & Medium \\
VIKOR & Moderate & Simple & Medium \\
ELECTRE & Moderate & Moderately critical & Medium \\
PROMETHEE & Moderate & Moderately critical & Medium \\
\hline
\end{tabular}

Brauers, W., \& Zavadskas, E. (2012). Robustness of MULTIMOORA: A Method for Multi-Objective Optimization. Informatica, 23(1), 1-25.

Table 1 lays out the comparison of MOORA method with other multi-criteria decision making methods. Having less and easier mathematical calculations and being more reliable compared to other methods, this method has been widely used in financial research.

Metin et al. (2017) ranked the performance of eleven energy companies which are publicly traded in Borsa Istanbul using multi-criteria decision making methods TOPSIS and MOORA, and commented on the results of the two different rankings. Ege and Yaman (2018) calculated TOPSIS and MOORA scores for the financial performance of BIST cement-concrete enterprises, analyzing the 6-month data in years 2010-2016. In the next step in their study, they investigated the relationship between these scores and share returns utilizing panel data analysis method. Ceyhan and Demirci (2017) used MULTIMOORA method in order to evaluate the financial performance of companies in Borsa Istanbul operating in leasing sector and ranked these companies. Ture et al. (2016) ranked 76 countries using MULTIMOORA method based on 22 macroeconomic variables with the help of 2012 data and obtained risk ranking of these countries. Stankeviciene et al. (2014) ranked EU Baltic Sea countries in terms of risk and sustainability using variables determined from 2012 data. MOORA method can be called different names when different algorithms are applied. These include ratio method, reference point approach, significance coefficient, full multiplication, and Multi-MOORA (Ersoz \& Atav, 2011: 79).

Since this study utilizes ratio method in order to rank countries' inevitability based on various macroeconomic variables and compare the results to those given by other rating agencies, it only includes the methodology for ratio method. Steps of MOORA ratio method can be explained as below:

\section{Step 1: Formation of decision matrix}

In order to implement MOORA method, the first step is to formulate an initial matrix. This matrix is created with the variable values and can be shown as below (Genc, Avci, \& Sevgin, 2017: 26).

$$
X=\left[\begin{array}{rlllc}
x_{11} & \ldots & x_{1 i} & \ldots & x_{1 n} \\
\vdots & \ddots & \vdots & . & \vdots \\
x_{j 1} & \ldots & x_{j i} & \ldots & x_{j n} \\
\vdots & . & \vdots & \ddots & \vdots \\
x_{m 1} & \ldots & x_{m i} & \ldots & x_{m n}
\end{array}\right]
$$

In the implementation of MOORA method, observed variable is named alternative and variable of interest is called criterion. Here, $x_{i j}$ refers to the value of $\mathrm{i}^{\text {th }}$ alternative at $\mathrm{j}^{\text {th }}$ criterion.

\section{Step 2: Normalization}

In order to accomplish normalization, values in the decision matrix are divided by the square root of the sum of squares of each alternative per criteria. The value of this ratio is calculated as below (Chand, Bhatia, \& Singh, 2018: 647). It is expected for this calculated value to be between 0 and 1 (Kalirasu, Rajini, Rajesh, Winowlin Jappes, \& Karuppasamy, 2017: 1733). 


$$
X_{i j}^{*}=\frac{x_{i j}}{\sqrt{\sum_{i=1}^{m} x_{i j}^{2}}}
$$

\section{Step 3: Scoring}

Normalized values are added in case of maximization for beneficial criteria and subtracted in case of minimization for non-beneficial criteria, resulting in a single value for each alternative (Ozdagoglu, 2014: 285). This can be demonstrated as follows (Onay, 2014: 247).

$$
y_{i}^{*}=\sum_{j=1}^{g} x_{i j}^{*}-\sum_{j=g+1}^{n} x_{i j}^{*}
$$

\section{Step 4: Ranking}

The method is completed by ranking $y_{i}{ }^{*}$ values obtained in step 3 from high to low.

\section{Implementation}

S\&P, Moody's and Fitch ratings, determined by analyzing economic, social and political variables, are significant criteria used in comparing countries and assessing whether they are feasible for economic investments. However, it may cause variations in country rankings to use different macroeconomic variables in the comparison of economic structures. Thus, in this study, MOORA method is utilized to rank countries by economic development using the variables in Table 2. In MOORA method, variables used are called criteria and countries analyzed are called alternatives.

Table 2. Macroeconomic Variables and Criterion Numbers

\begin{tabular}{|c|l|}
\hline Criteria No & Definition of Criteria \\
\hline C1 & Foreign direct investment, net inflows (BoP, current US\$) \\
\hline C2 & Industry, value added (\% of GDP) \\
\hline C3 & Gross savings (\% of GDP) \\
\hline C4 & Inflation, consumer prices (annual \%) \\
\hline C5 & Services, etc., value added (\% of GDP) \\
\hline C6 & Total reserves (includes gold, current US\$) \\
\hline C7 & $\begin{array}{l}\text { Charges for the use of intellectual property, payments (BoP, } \\
\text { current US\$) }\end{array}$ \\
\hline C8 & GDP (current US\$) \\
\hline C9 & Gross capital formation (\% of GDP) \\
\hline C10 & Labor force, total \\
\hline C11 & Domestic credit to private sector (\% of GDP) \\
\hline C12 & Merchandise imports (current US\$) \\
\hline
\end{tabular}

Table 2 includes variables that are selected from World Bank database in such a way that each variable is relevant to all the countries (The World Bank, 2018). Moreover, they will be addressed by criterion numbers in the upcoming sections of the study. The variables used for ranking countries can be explained as below:

Foreign direct investment, net inflows (BoP, current US\$): Foreign direct investments refer to net investment inflows with the intention of acquiring a permanent management activity (10 percent or more vote power) in an enterprise that operate in a different economy than the investor. As FDI contribute to the host country in terms of capital, technology, governance and employment, it is in parallel with country rating.

Industry, value added (\% of GDP): Industry refers to actions taken to convert raw materials into processed products, as well as all the tools used to this end. It is obtained by summing all outputs and 
subtracting all inputs in the industry sector and then dividing the result by country GDP. Consequently, it is directly proportional with country ratings.

Gross savings (\% of GDP): Gross savings can be defined as the difference between current income and current consumption expenditures of a nation's economy. Since savings take their form based on the economic structure of each country, saving accumulation and saving usage have different characteristics among underdeveloped, developing and developed countries. For example in developed countries, private savings have higher levels and individuals and companies have more income than expense, which allow for saving. However, the situation in developing countries is different in that the sufficient saving rate cannot be met in these countries.

Inflation, consumer prices (annual \%): Inflation measured on the basis of consumer price index is the reflection on the consumer, of change in goods and services that can be mobilized or immobilized on certain intervals for the consumer. Inflation rate is a valuable knowledge for investors, which enables them to know how much value today's money will have in the future and to determine future income streams by reducing them with inflation. Since inflation can create a politically unstable atmosphere, it has adverse effect on country ratings.

Services, etc., value added (\% of GDP): It is the share of service effect on national economy in GDP. It is one of the fundamental indicators of a country's level of development.

Total reserves (includes gold, current US\$): Total reserves include monetary gold, reserves of a country and exchange assets under the control of monetary authorities. The gold component of these reserves is valued at year-end (December 31) London prices. Thus, rise in total reserves of a country is expected to raise the country's rating.

Charges for the use of intellectual property, payments (BOP, current US\$): It includes charges for the use of properties such as patents, trademarks, copyrights, industrial processes. As charges for the use of property reflect how much productive work is created within an economy, they are in parallel with sovereign ratings.

GDP (current US\$): GDP is one of the major indicators of a country's economic size. GDP is defined as the value in terms of currency that is the sum of total goods and service produced within a country's borders in a specific time period minus intermediate goods used for the production. It is calculated without cutting the amount of depreciation of produced assets or the amount of natural resources consumed or deteriorated. While increase in GDP does not imply an increase in welfare, it implies an increase in income, hence it is directly proportional with country rating.

Gross capital formation (\% of GDP): It consists of the construction of fixed assets of economy, namely land improvements, purchase of facilities, machinery and equipment, schools, hospitals, private houses, commercial and industrial buildings as well as roads, railways, etc., and also expenses on net changes in stock level.

Labor force, total: Labor force is the supply of available labor for production of goods and services in an economy. Total labor force is comprised of people from the economically active population, who are aged 15 or older and comply with the definition of "International Labor Organization" (anyone who supplied labor for production of goods and services for a specified period of time). It does not include armed forces, seasonal or part-time workers, and workers in unrecorded sectors.

Domestic credit to private sector (\% of GDP): It refers to financial resources provided to private sector.

Merchandise imports (current US\$): It is data about trade in goods, obtained by customs reports of goods entering in a nation's economy or registered in balance payments.

As a result of the meetings with scientists who are experts in their fields and engaged in the fields of economy and finance considering the aforementioned variables, it was recommended to minimize only the criterion $\mathrm{C} 4$ and maximize the rest of the criteria, $\mathrm{C} 1, \mathrm{C} 2, \mathrm{C} 3, \mathrm{C} 5, \mathrm{C} 6, \mathrm{C} 7, \mathrm{C} 8, \mathrm{C} 9, \mathrm{C} 10, \mathrm{C} 11$ and $\mathrm{C} 12$, for determining the ranking of countries that will help find out the economic superiority of countries to each 
other. Based on this, values obtained by normalizing the criteria which were identified for 96 countries (alternatives) and the resulting $\mathrm{y}^{*}$ values which was calculated based on optimization are given in Appendix 1 for each alternative. Ranking $\mathrm{y}^{*}$ values in Appendix 1 from high to low also ranks countries from better to lower in terms of macroeconomic variables.

This ranking created in this study is compared to sovereign ratings by the international credit rating agencies, S\&P, Moody's, and Fitch. But prior to this comparison, the rating scores of countries assigned by credit rating agencies and their meaning in literature are shown in Table 3 (S\&P; Moody's; Fitch, 2018). In order to demonstrate the result of the study in a visually better manner, the meaning of the scores are colorcoded and ordinal values for each score are also provided. These values are presented in Table 3.

Table 3. International Credit Rating Agencies Scores, Meanings, and Color-Coding

\begin{tabular}{|c|c|c|c|c|}
\hline No & S\&P & Moody's & Fitch & Meaning and Color \\
\hline 1 & AAA & Aaa & AAA & Prime \\
\hline 2 & AA+ & Aa1 & $\mathrm{AA}+$ & \multirow{3}{*}{ High Grade } \\
\hline 3 & $\mathrm{AA}$ & $\mathrm{Aa} 2$ & $\mathrm{AA}$ & \\
\hline 4 & AA- & Aa3 & AA & \\
\hline 5 & $A+$ & A1 & $A+$ & \multirow{3}{*}{ Upper Medium Grade } \\
\hline 6 & A & $\mathrm{A} 2$ & A & \\
\hline 7 & A- & A3 & A- & \\
\hline 8 & $\mathrm{BBB}+$ & Baa1 & $\mathrm{BBB}+$ & \multirow{3}{*}{ Lower Medium Grade } \\
\hline 9 & BBB & Baa2 & BBB & \\
\hline 10 & BBB- & Baa3 & BBB- & \\
\hline 11 & $\mathrm{BB}+$ & Ba1 & $\mathrm{BB}+$ & \multirow{3}{*}{$\begin{array}{l}\text { Non Investment Grade } \\
\text { Speculative }\end{array}$} \\
\hline 12 & BB & $\mathrm{Ba} 2$ & $\mathrm{BB}$ & \\
\hline 13 & BB- & $\mathrm{Ba} 3$ & BB- & \\
\hline 14 & $\mathrm{~B}+$ & B1 & $\mathrm{B}+$ & \multirow{3}{*}{ Highly Speculative } \\
\hline 15 & $\mathrm{~B}$ & B2 & $\mathrm{B}$ & \\
\hline 16 & B- & B3 & B- & \\
\hline 17 & $\mathrm{CCC}+$ & Caa1 & $\mathrm{CCC}+$ & Substantial Risks \\
\hline 18 & $\mathrm{CCC}$ & Caa2 & $\mathrm{CCC}$ & Extremely Speculative \\
\hline
\end{tabular}

To enable comparison of rankings obtained from international credit rating agencies and MOORA method, countries' MOORA ranking is distributed with the assumption that it will be distributed approximately equally over each score color, and these are colored accordingly. Thus, the countries that were assigned the prime scores by credit rating agencies are compared to the topmost 13 countries in MOORA ranking and rank values for these countries are coded with the color red. Other colors can be explained likewise with the color scale in Table 3. Hence, Table 4 presents MOORA rankings and S\&P, Moody's, and Fitch rating categories of countries.

Examining Table 4, it is observed that Netherlands, Germany, Singapore, Switzerland and Canada are assign the Prime status by all the credit rating agencies; at the same time, these countries are among the top 13 countries in the MOORA ranking which was created with the help of the macroeconomic variables that were determined in this study. China, Ireland and Japan are assigned Upper Medium Grade by the credit rating agencies, while these countries made such high scores in MOORA method that they were categorized as Prime countries in MOORA ranking. On the other hand, India is among lower medium and highly speculative countries in the ratings by the credit rating agencies due to its rising acceleration in trade, while it is placed among prime countries in the rankings created by using the before mentioned macroeconomic variables. Other countries can be commented upon in similar ways.

The next part of the study presents the comparison of scoring by international credit rating agencies and rankings obtained with MOORA method. 
Comparison of Country Ratings of Credit Rating Agencies with MOORA Method

Table 4. MOORA Rankings and S\&P, Moody's and Fitch Categories of Countries

\begin{tabular}{|c|c|c|c|c|c|c|c|c|c|c|c|c|c|c|}
\hline Countries & MOORA & S\&P & Moody's & Fitch & Countries & MOORA & S\&P & Moody's & Fitch & Countries & MOORA & S\&P & Moody's & Fitch \\
\hline Netherlands & 6 & 1 & 1 & 1 & Japan & 3 & 5 & 5 & 6 & Cyprus & 38 & 11 & 13 & 12 \\
\hline Singapore & 9 & 1 & 1 & 1 & Lithuania & 75 & 6 & 7 & 7 & Brazil & 19 & 13 & 12 & 13 \\
\hline Canada & 13 & 1 & 1 & 1 & Slovenia & 63 & 5 & 15 & 7 & Bangladesh & 41 & 13 & 13 & 13 \\
\hline Australia & 18 & 1 & 1 & 1 & Spain & 15 & 8 & 16 & 7 & Dominica & 71 & 13 & 13 & 13 \\
\hline Sweden & 24 & 1 & 1 & 1 & Mexico & 22 & 8 & 7 & 8 & Vietnam & 27 & 13 & 14 & 13 \\
\hline Luxembourg & 43 & 1 & 1 & 1 & Kazakhstan & 82 & 10 & 10 & 9 & Kenya & 91 & 14 & 15 & 14 \\
\hline United States & 2 & 2 & 1 & 1 & Indonesia & 20 & 10 & 10 & 9 & Rwanda & 89 & 15 & 15 & 14 \\
\hline Finland & 49 & 2 & 2 & 2 & Portugal & 51 & 10 & 11 & 9 & Uganda & 84 & 15 & 15 & 14 \\
\hline Austria & 46 & 2 & 2 & 2 & Philippines & 32 & 9 & 16 & 9 & Nigeria & 92 & 15 & 15 & 14 \\
\hline Hong Kong SAR, China & 12 & 5 & 3 & 2 & Bulgaria & 55 & 10 & 16 & 9 & Nicaragua & 73 & 14 & 15 & 14 \\
\hline New Zealand & 61 & 3 & 1 & 3 & \begin{tabular}{|l|} 
Panama \\
\end{tabular} & 29 & 9 & 16 & 9 & Ethiopia & 59 & 15 & 14 & 15 \\
\hline Belgium & 28 & 3 & 4 & 4 & Russian Federation & 17 & 10 & 11 & 10 & Jamaica & 78 & 15 & 16 & 15 \\
\hline Qatar & 23 & 4 & 4 & 4 & Morocco & 45 & 10 & 11 & 10 & Zambia & 83 & 15 & 16 & 15 \\
\hline Poland & 33 & 8 & 6 & 4 & Uruguay & 88 & 9 & 16 & 10 & Egypt, Arab Rep. & 90 & 16 & 16 & 15 \\
\hline Malaysia & 25 & 7 & 7 & 4 & India & 7 & 10 & 16 & 10 & Ghana & 93 & 16 & 16 & 15 \\
\hline Czech Republic & 35 & 4 & 5 & 5 & Oman & 36 & 12 & 16 & 10 & Ecuador & 65 & 16 & 16 & 15 \\
\hline Estonia & 53 & 4 & 5 & 5 & South Africa & 44 & 12 & 10 & 11 & Greece & 66 & 15 & 16 & 15 \\
\hline China & 1 & 5 & 5 & 5 & Azerbaijan & 70 & 11 & 12 & 11 & Belarus & 86 & 15 & 17 & 15 \\
\hline Israel & 40 & 5 & 5 & 5 & Turkey & 34 & 12 & 12 & 11 & Suriname & 94 & 15 & 15 & 16 \\
\hline Saudi Arabia & 21 & 7 & 5 & 5 & Croatia & 58 & 12 & 12 & 11 & Mongolia & 52 & 16 & 16 & 16 \\
\hline Ireland & 4 & 5 & 6 & 5 & Paraguay & 80 & 12 & 11 & 12 & Lebanon & 57 & 16 & 16 & 16 \\
\hline Slovak Republic & 50 & 5 & 6 & 5 & Guatemala & 85 & 13 & 11 & 12 & El Salvador & 81 & 17 & 16 & 16 \\
\hline Malta & 48 & 7 & 7 & 5 & Costa Rica & 72 & 13 & 12 & 12 & Iraq & 62 & 16 & 17 & 16 \\
\hline
\end{tabular}

Table 5. Comparison of S\&P Scores and MOORA Rankings of Countries

\begin{tabular}{|c|c|c|c|c|c|c|c|c|c|}
\hline \multicolumn{10}{|c|}{ Standard and Poor's Rating Services } \\
\hline \multirow{8}{*}{$\frac{\pi}{8}$} & $n=96$ & Prime & High Grade & $\begin{array}{c}\text { Upper } \\
\text { Medium } \\
\text { Grade }\end{array}$ & $\begin{array}{c}\text { Lower } \\
\text { Medium } \\
\text { Grade }\end{array}$ & $\begin{array}{c}\text { Non } \\
\text { Investment } \\
\text { Grade } \\
\text { Speculative }\end{array}$ & $\begin{array}{c}\text { Highly } \\
\text { Speculative }\end{array}$ & $\begin{array}{l}\text { Substantial } \\
\text { Risks }\end{array}$ & \multirow{8}{*}{$\begin{array}{l}37.50 \% \\
\text { Optimistic }\end{array}$} \\
\hline & Prime & $5(50.00 \%)$ & 3 & 4 & 1 & 0 & 0 & 0 & \\
\hline & High Grade & 3 & $1(8.30 \%)$ & 2 & 6 & 2 & 0 & 0 & \\
\hline & $\begin{array}{l}\text { Upper Medium } \\
\text { Grade }\end{array}$ & 1 & 4 & $1(7.10 \%)$ & 4 & 4 & 0 & 0 & \\
\hline & $\begin{array}{c}\text { Lower Medium } \\
\text { Grade }\end{array}$ & 1 & 3 & 3 & $4(21.00 \%)$ & 1 & 2 & 0 & \\
\hline & $\begin{array}{c}\text { Non Investment } \\
\text { Grade Speculative }\end{array}$ & 0 & 1 & 3 & 2 & $2(12.50 \%)$ & 6 & 0 & \\
\hline & Highly Speculative & 0 & 0 & 1 & 1 & 6 & $5(20.80 \%)$ & 1 & \\
\hline & Substantial Risks & 0 & 0 & 0 & 1 & 1 & 11 & 0 & \\
\hline
\end{tabular}

Table 5 shows the evaluation on S\&P scores and MOORA ranking groups of 96 countries analyzed. The ratios of countries in the same group are shown in the diagonal. 5 countries categorized as prime by S\&P are also categorized as prime in the MOORA ranking. Thus, $50 \%$ of the countries categorized as prime by S\&P are also in the same category in the MOORA ranking. Similarly, $8.30 \%$ of the countries categorized as high grade by S\&P are also in the same category in the MOORA ranking. Among 5 countries in the Prime category in S\&P scoring, 3 are in high grade, 1 is in upper medium grade and 1 is in lower medium grade category in the MOORA ranking. $37.50 \%$ of 96 countries are categorized in a higher group in the MOORA ranking created 
by using the variables which were selected in this study, compared to categories based on S\&P scores. On the other hand, $43.75 \%$ of these countries are placed in a lower category than S\&P score categories.

Table 6. Comparison of Moody's Scores and MOORA Rankings of Countries

\begin{tabular}{|c|c|c|c|c|c|c|c|c|c|}
\hline \multicolumn{10}{|c|}{ Moody's Corporation } \\
\hline \multirow{9}{*}{$\frac{3}{8}$} & $n=96$ & Prime & High Grade & $\begin{array}{l}\text { Upper } \\
\text { Medium } \\
\text { Grade }\end{array}$ & $\begin{array}{l}\text { Lower } \\
\text { Medium } \\
\text { Grade }\end{array}$ & $\begin{array}{c}\text { Non } \\
\text { Investment } \\
\text { Grade } \\
\text { Speculative }\end{array}$ & $\begin{array}{c}\text { Highly } \\
\text { Speculative }\end{array}$ & $\begin{array}{l}\text { Substantial } \\
\text { Risks }\end{array}$ & \multirow{9}{*}{$\begin{array}{c}38.54 \% \\
\text { Optimistic }\end{array}$} \\
\hline & Prime & $6(50.00 \%)$ & 3 & 3 & 0 & 0 & 1 & 0 & \\
\hline & High Grade & 3 & $1(10.00 \%)$ & 3 & 1 & 2 & 4 & 0 & \\
\hline & $\begin{array}{l}\text { Upper Medium } \\
\text { Grade }\end{array}$ & 1 & 3 & $3(18.75 \%)$ & 1 & 3 & 3 & 0 & \\
\hline & $\begin{array}{c}\text { Lower Medium } \\
\text { Grade }\end{array}$ & 1 & 3 & 3 & $2(40.00 \%)$ & 2 & 3 & 0 & \\
\hline & $\begin{array}{c}\text { Non Investment } \\
\text { Grade Speculative }\end{array}$ & 1 & 0 & 3 & 0 & $2(12.50 \%)$ & 7 & 1 & \\
\hline & Highly Speculative & 0 & 0 & 1 & 1 & 6 & $6(17.65 \%)$ & 0 & \\
\hline & Substantial Risks & 0 & 0 & 0 & 0 & 1 & 10 & $2(66.67 \%)$ & \\
\hline & & \multicolumn{7}{|c|}{ 38.54\% Pessimistic } & \\
\hline
\end{tabular}

Table 6 shows the evaluation on Moody's scores and MOORA ranking groups of 96 countries analyzed. The ratios of countries in the same group are shown in the diagonal in this table, as in Table 5. 2 countries categorized as lower medium grade by Moody's are also categorized as lower medium grade in the MOORA ranking. Thus, $40 \%$ of the countries categorized as lower medium grade by Moody's are also in the same category in the MOORA ranking. Among 34 countries in the highly speculative category in Moody's rating, 1 is in prime, 4 are in high grade, 3 are in upper medium grade, 3 are in lower medium grade, 7 are in non-investment grade speculative, 6 are in highly speculative and 10 are in substantial risk categories in the MOORA ranking. Compared to Moody's rating categories, 38.54\% of 96 countries are categorized in a higher group in the MOORA ranking created by using the variables which were selected in this study. On the other hand, $38.54 \%$ of these countries are placed in a lower category than Moody's score categories.

Table 7. Comparison of Fitch Scores and MOORA Rankings of Countries

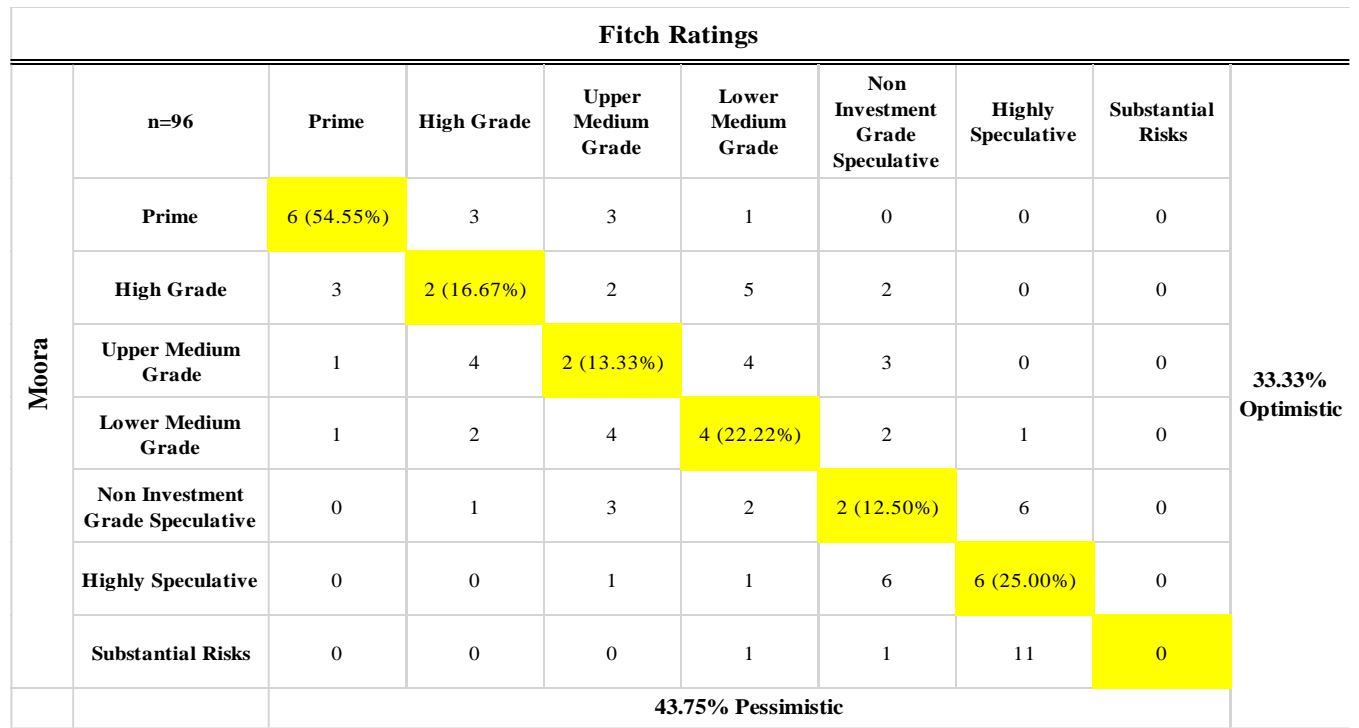


Table 7 shows the evaluation on Fitch scores and MOORA ranking groups of 96 countries analyzed. As can be seen in the table, 6 countries categorized as prime by Fitch are also categorized as prime in the MOORA ranking. Thus, $54.55 \%$ of the countries categorized as prime by Fitch are also in the same category in the MOORA ranking. 10 countries categorized as lower medium by Fitch are in higher categories in the MOORA ranking. In addition, 11 countries assessed as highly speculative by the Fitch rating are in substantial risk category in the MOORA ranking. Other values can be interpreted in a similar manner. Compared to Fitch rating categories, $33.33 \%$ of 96 countries are categorized in a higher group in the MOORA ranking created by using the variables which were selected in this study. On the other hand, $43.75 \%$ of these countries are placed in a lower category than Moody's score categories.

\section{Conclusion}

The three main credit rating agencies, S\&P, Moody's, and Fitch, use a combination of economic, social and political factors in order to assess the capacity and current and future debt obligation of countries. This study contributes to literature in two ways. The first one is comparison of results obtained by rating countries on various macroeconomic variables using credit scores given by the three main credit rating agencies and using the MOORA method. The second one is the determination of how optimistic or pessimistic countrybased results the three main CRAs yield according to their estimates by macroeconomic variables.

Examining the MOORA ranking created with the help of macroeconomic variables, it is seen that Netherlands, Germany, Singapore, Switzerland and Canada which are in the top thirteen countries are assigned the prime status by all of the credit rating agencies. Although China, Ireland and Japan are put in upper medium grade category and India in lower medium and highly speculative category by the credit rating agencies, they made such high scores in MOORA method that they were categorized as prime countries in MOORA ranking. Even though CRAs not always agree with each other, the difference is usually limited to one or two points; however, the MOORA method implemented with macroeconomic variables yielded quite different ratings. Lithuania (ranked $75^{\text {th }}$ ) was placed in upper medium grade category by the three main CRA, and Kazakhstan (ranked $82^{\text {nd }}$ ) was assigned lower medium grade. However, the result of the analysis yielded highly speculative.

Moreover, when the credit ratings for 96 countries by the three main CRA are compared to the ranking of the countries using the MOORA method with various macroeconomic variables, the highest levels of similarity was observed in Moody's credit rating agency with substantial risks category (66.67\%), followed by prime category of Fitch (54.55\%) and S\&P (50\%). Thus, countries that are at the top and bottom of the sovereign ratings by CRAs based on economic, social and political variables are also at the top and bottom according to macroeconomic variables, indicating similar results with this study. It was observed that, among the credit rating agencies, Moody's estimates for these 96 countries are slightly more optimistic compared to other rating agencies (38.54\%), followed by S\&P (37.5\%) and Fitch (33.33\%). This also gives a similar result in more pessimistic estimates for countries. The most pessimistic estimates for the countries in terms of credit rating categories belong to S\&P and Fitch with a percentage of $43.75 \%$.

Drawing a conclusion from all of the above, among the three rating agencies, Moody's make the most optimistic estimates in terms of its rating of countries. Moody's is followed by S\&P, and the CRA that make the most pessimistic estimates is observed to be Fitch.

\section{References}

Abad, P., \& Robles, M. D. (2014). Credit rating agencies and idiosyncratic risk: Is there a linkage? Evidence from the Spanish market. International Review of Economics and Finance, 33, 152-171.

Arezki, R., Candelon, B., \& Amadou, N.R. (2011). Sovereign rating news and financial markets spillovers: Evidence from the European debt. IMF Working Paper, 11(68), 1-27.

Baghai, R., \& Becker, B. (2018, January). Non-rating revenue and conflicts of interest. Journal of Financial Economics, 127(1), 94-112. 
Baum, A., Checherita-Westphal, C., \& Rother. (2012). Debt and growth new evidence for the Euro area. European Central Bank Working Papers, 1-20.

Brauers, W., \& Zavadkas, E. (2012). Robustness of MULTIMOORA: A method for multi-objective optimization. Informatica, 23(1), 1-25.

Brauers, W., \& Zavadskas, E. (2006). The MOORA method and its application to privatization in a transition economy. Control and Cybernetics, 35(2), 445-469.

Bodenstedt, M., Rösch, D., \& Scheule, H. (2013). The path to impairment: Do credit-rating agencies anticipate default events of structured finance transactions? European Journal of Finance, 19(9), 841-860.

Bozic, V., \& Magazzino, C. (2013). Credit rating agencies: The importance of fundamentals in the assessment of sovereign ratings. Economic Analysis and Policy, 43(2), 157-176.

Ceyhan, I., \& Demirci, F. (2017). Measurement of financial performance with MULTIMOORA Method: A study at leasing companies. Bartin University Journal of Faculty of Economics \& Administrative Sciences, 8(15), 277-295.

Chand, M., Bhatia, N., \& Singh, R. (2018). ANP-MOORA-Based approach for the analysis of selected issues of green supply chain management. Benchmarking An International Journal, 25(2), 642-659.

Ege, I., \& Yaman, S. (2018). The effects of financial performance that measured by TOPSIS and MOORA methods on stock returns: A panel data application on bist cement-concrete companies. INJOSOS Al-Farabi International Journal on Social Sciences, 2(1), 75-96.

Erdem, O., \& Varli, Y. (2014, September). Understanding the sovereign credit ratings of emerging markets. Emerging Markets Review, 20, 42-57.

Ersoz, F., \& Atav, A. (2011). MOORA Method in an objective multi-criteria decisions problems. YAEM 2011 31st National Congress of Operations Research and Industrial Engineering (p. 78-87). Sakarya: Sakarya University.

Freitag, L. (2015). Procyclicality and path dependence of sovereign credit ratings: The example of Europe. Economic Notes, 44(2), 309-332.

Genc, A., Avci, T., \& Sevgin, H. (2017).An activity analysis on the black sea economic cooperation member countries: An application with TOPSIS, ARAS and MOORA methods. Pamukkale Journal of Eurasian Socioeconomic Studies, 4(2), 15-40.

Hamdi, A., Herwany, A., \& Tanzil, N. A. (2015). The comparison analysis of macroeconomics determinant sovereign credit rating and its impact to stock market (evidence for the emerging market countries). International Journal of Applied Business and Economic Research, 13(7), 5065-5078.

Hill, P., Brooks, R., \& Faff, R. (2010). Variations in sovereign credit quality assessments across rating agencies. Journal of Banking and Finance, 34(6), 1327-1343.

loannous, S. (2018). Sovereign ratings, macroeconomis dynamics and fiscal policy. Interactions within a stock flow consistent framework. Metroeconomica, 69(1), 151-177.

Kabadayi, B., \& Celik, A. A. (2015). Determinants of sovereign ratings in emerging countries: A qualitative, dependent variable panel data analysis. International Journal of Economics and Financial Issues, 5(3), 656-662.

Kalirasu, S., Rajini, N., Rajesh, S., Winowlin Jappes, J., \& Karuppasamy, K. (2017). AWJM Performance of jute/polyester composite using MOORA and analytical models. Materials and Manufacturing Processes, 35(15), 1730-1739.

Karminsky, A., \& Khromova, E. (2016). Modelling banks' credit ratings of international agencies. Eurasion Economic Review, 6(3), 341-363.

Kunovac, D., \& Ravnik, R. (2018). Are sovereign credit ratings overrated? Comparative Economic Studies, 59(2), $210-242$.

Mardani, A., Jusoh, A., Nor, K., Khalifah, Z., Zakwan, N., \& Valipour, A. (2015). Multiple criteria decision-making techniques and their applications - A review of the literature from 2000 to 2014. Economic Research, 28(1), 516571.

Martin-Garcia, M., Tellez-Valle, C., \& Martin-Marin, J. L. (2014). Evolution of sovereign rating models in the current crisis. Journal Globazilization Competitiveness and Governability, 8(1), 16-33.

Mellios, C., \& Paget-Blanc, E. (2006). Which factors determine sovereign credit ratings? European Journal of Finance, 11(4), 361-377.

Metin, S., Yaman, S., \& Korkmaz, T. (2017). Determination of the financial performance by TOPSIS and MOORA methods: A comparative application on BIST energy companies. Journal of KSU Social Science, 14(2), 371-394.

Ozturk, H. (2016). Reliance of sovereign credit ratings on governance indicators. European Journal of Development Reserch, 28(2), 184-212. 
Onay, O. (2014). MOORA. In B. Yıldırım, \& E. Onder (Ed.), Multi-criteria decisions methods. Istanbul: Dora Publication.

Ozdagoglu, A. (2014). The effects of the normalization methods to multicriteri decision making process MOORA method review. Aegean Academic Overview, 14(2), 283-294.

Stankeviciene, J., Sviderske, T., \& Miecinskiene, A. (2014). Dependence of sustainability on country risk indicators in EU Baltic Sea region countries. Journal of Business Economics \& Management, 15(4), 646-663.

The World Bank. (2018, January 25). Databank. January 25, 2018 Statistics: http://databank.worldbank.org/data/

Ture, H., Kocak, D., \& Dogan, S. (2016). Country risk assestment with MULTIMOORA method. Gazi University Journal of Economics and Administrative Sciences, 18(3), 824-844. 


\section{Appendix}

Appendix 1. Result of MOORA Method

\begin{tabular}{|c|c|c|c|c|c|c|c|c|c|c|c|c|c|}
\hline Normalization & $\max$ & $\max$ & $\max$ & $\min$ & $\max$ & $\max$ & $\max$ & $\max$ & $\max$ & $\max$ & $\max$ & $\max$ & \\
\hline Alternatives & C1 & $C 2$ & C3 & C4 & C5 & C6 & C7 & C8 & C9 & C10 & C11 & C12 & $y^{*}$ \\
\hline Angola & 0.006 & 0.218 & 0.012 & 0.411 & 0.043 & 0.007 & 0.002 & 0.004 & 0.034 & 0.012 & 0.025 & 0.004 & -0.046 \\
\hline Argentina & 0.005 & 0.090 & 0.056 & 0.316 & 0.104 & 0.011 & 0.019 & 0.023 & 0.066 & 0.020 & 0.016 & 0.016 & 0.109 \\
\hline Australia & 0.065 & 0.082 & 0.088 & 0.015 & 0.115 & 0.015 & 0.030 & 0.051 & 0.102 & 0.013 & 0.166 & 0.057 & 0.769 \\
\hline Austria & -0.046 & 0.093 & 0.106 & 0.011 & 0.112 & 0.007 & 0.012 & 0.017 & 0.094 & 0.005 & 0.098 & 0.046 & 0.533 \\
\hline Azerbaijan & 0.007 & 0.174 & 0.087 & 0.049 & 0.067 & 0.002 & 0.000 & 0.002 & 0.100 & 0.005 & 0.031 & 0.003 & 0.427 \\
\hline Bahrain & 0.000 & 0.134 & 0.079 & 0.033 & 0.095 & 0.001 & 0.000 & 0.001 & 0.119 & 0.001 & 0.086 & 0.003 & 0.484 \\
\hline Bangladesh & 0.003 & 0.097 & 0.151 & 0.065 & 0.089 & 0.009 & 0.000 & 0.009 & 0.119 & 0.066 & 0.052 & 0.013 & 0.543 \\
\hline Belarus & 0.002 & 0.122 & 0.089 & 0.140 & 0.088 & 0.001 & 0.001 & 0.002 & 0.101 & 0.005 & 0.025 & 0.008 & 0.305 \\
\hline Belgium & 0.057 & 0.075 & 0.091 & 0.023 & 0.122 & 0.007 & 0.027 & 0.020 & 0.096 & 0.005 & 0.075 & 0.108 & 0.658 \\
\hline Bolivia & 0.001 & 0.104 & 0.061 & 0.043 & 0.088 & 0.003 & 0.001 & 0.001 & 0.083 & 0.005 & 0.075 & 0.002 & 0.381 \\
\hline Brazil & 0.120 & 0.071 & 0.057 & 0.103 & 0.116 & 0.102 & 0.046 & 0.077 & 0.062 & 0.104 & 0.072 & 0.042 & 0.766 \\
\hline Bulgaria & 0.002 & 0.095 & 0.108 & -0.009 & 0.106 & 0.007 & 0.002 & 0.002 & 0.077 & 0.003 & 0.061 & 0.008 & 0.481 \\
\hline Cameroon & 0.000 & 0.090 & 0.068 & 0.010 & 0.090 & 0.001 & 0.000 & 0.001 & 0.089 & 0.010 & 0.018 & 0.001 & 0.358 \\
\hline Canada & 0.049 & 0.097 & 0.077 & 0.017 & 0.110 & 0.023 & 0.087 & 0.065 & 0.092 & 0.020 & 0.144 & 0.121 & 0.869 \\
\hline Chile & 0.019 & 0.105 & 0.082 & 0.045 & 0.102 & 0.011 & 0.014 & 0.011 & 0.087 & 0.009 & 0.130 & 0.017 & 0.542 \\
\hline China & 0.262 & 0.134 & 0.188 & 0.024 & 0.082 & 0.867 & 0.216 & 0.478 & 0.178 & 0.794 & 0.182 & 0.460 & 3.817 \\
\hline Colombia & 0.021 & 0.110 & 0.078 & 0.089 & 0.095 & 0.013 & 0.004 & 0.012 & 0.102 & 0.026 & 0.055 & 0.013 & 0.440 \\
\hline Costa & 0.005 & 0.072 & 0.061 & 0.000 & 0.115 & 0.002 & 0.005 & 0.002 & 79 & 0.002 & .069 & .004 & 0.419 \\
\hline Croatia & 0.003 & 0.088 & 0.092 & -0.013 & 0.110 & 0.004 & 0.002 & 0.002 & 0.080 & 0.002 & 0.071 & 0.006 & 0.474 \\
\hline Cyprus & 0.004 & 0.038 & 0.047 & -0.017 & 0.137 & 0.000 & 0.001 & 0.001 & 0.066 & 0.001 & 0.264 & 0.002 & 0.577 \\
\hline Czech Repu & 0.010 & 0.127 & 0.107 & 0.008 & 0.095 & 0.024 & 0.011 & 0.008 & 0.106 & 0.005 & 0.060 & 0.041 & 0.586 \\
\hline Denmark & 0.010 & 0.079 & 0.116 & 0.003 & 0.119 & 0.018 & 0.015 & 0.013 & 0.084 & 0.003 & 0.198 & 0.025 & 0.676 \\
\hline Dominica & 0.000 & 0.046 & 0.092 & 0.003 & 0.106 & 0.000 & 0.000 & 0.000 & 0.100 & 0.028 & 0.054 & 0.000 & 0.424 \\
\hline Ecuador & 0.001 & 0.117 & 0.109 & 0.020 & 0.087 & 0.001 & 0.000 & 0.004 & 0.101 & 0.008 & 0.034 & 0.005 & 0.446 \\
\hline Egypt.ArapRep. & 0.012 & 0.111 & 0.038 & 0.164 & 0.087 & 0.007 & 0.002 & 0.014 & 0.060 & 0.031 & 0.040 & 0.016 & 0.254 \\
\hline El Salvador & 0.001 & 0.089 & 0.048 & 0.007 & 0.099 & 0.001 & 0.001 & 0.001 & 0.055 & 0.003 & 0.053 & .003 & 0.345 \\
\hline Estonia & 0.001 & 0.091 & 0.105 & 0.002 & 0.111 & 0.000 & 0.000 & 0.001 & 0.097 & 0.001 & 0.083 & 0.004 & 0.493 \\
\hline Ethiopia & 0.006 & 0.072 & 0.115 & 0.086 & 0.066 & 0.001 & 0.000 & 0.003 & 0.160 & 0.050 & 0.082 & 0.005 & 0.473 \\
\hline Finland & -0.015 & 0.091 & 0.085 & 0.004 & 0.111 & 0.003 & 0.008 & 0.010 & 0.088 & 0.003 & 0.110 & 0.018 & 0.507 \\
\hline France & 0.054 & 0.066 & 0.084 & 0.002 & 0.125 & 0.041 & 0.119 & 0.105 & 0.092 & 0.031 & 0.113 & 0.166 & 0.994 \\
\hline Georgia & 0.002 & 0.084 & 0.081 & 0.025 & 0.105 & 0.001 & 0.000 & 0.001 & 0.131 & 0.002 & 0.072 & 0.002 & 0.455 \\
\hline Germany & 0.081 & 0.103 & 0.112 & 0.006 & 0.109 & 0.052 & 0.095 & 0.149 & 0.077 & 0.044 & 0.090 & 0.306 & 1.210 \\
\hline Ghana & 0.005 & 0.095 & 0.065 & 0.207 & 0.083 & 0.002 & 0.000 & 0.002 & 0.092 & 0.013 & 0.023 & 0.004 & 0.176 \\
\hline Greece & 0.005 & 0.055 & 0.045 & -0.010 & 0.126 & 0.002 & 0.002 & 0.008 & 0.043 & 0.005 & 0.126 & 0.014 & 0.440 \\
\hline Guatemala & 0.002 & 0.092 & 0.058 & 0.053 & 0.097 & 0.003 & 0.002 & 0.003 & 0.052 & 0.007 & 0.040 & 0.005 & 0.307 \\
\hline Hong Kong S.C. & 0.180 & 0.026 & 0.104 & 0.028 & 0.146 & 0.027 & 0.017 & 0.014 & 0.087 & 0.004 & 0.236 & 0.159 & 0.971 \\
\hline Hungary & 0.106 & 0.103 & 0.095 & 0.005 & 0.103 & 0.007 & 0.013 & 0.005 & 0.079 & 0.005 & 0.040 & 0.027 & 0.577 \\
\hline Iceland & -0.002 & 0.076 & 0.120 & 0.020 & 0.112 & 0.002 & 0.001 & 0.001 & 0.086 & 0.000 & 0.101 & 0.002 & 0.480 \\
\hline India & 0.068 & 0.097 & 0.123 & 0.058 & 0.085 & 0.101 & 0.049 & 0.097 & 0.122 & 0.517 & 0.058 & 0.104 & 1.363 \\
\hline Indonesia & 0.006 & 0.137 & 0.131 & 0.042 & 0.072 & 0.033 & 0.016 & 0.040 & 0.138 & 0.126 & 0.046 & 0.039 & 0.741 \\
\hline Iraq & 0.000 & 0.126 & 0.050 & 0.016 & 0.091 & 0.013 & 0.000 & 0.007 & 0.083 & 0.010 & 0.081 & 0.011 & 0.456 \\
\hline Ireland & 0.122 & 0.132 & 0.136 & 0.000 & 0.094 & 0.001 & 0.686 & 0.013 & 0.131 & 0.002 & 0.055 & 0.023 & 1.395 \\
\hline Israel & 0.018 & 0.070 & 0.099 & -0.006 & 0.123 & 0.027 & 0.011 & 0.014 & 0.082 & 0.004 & 0.076 & 0.020 & 0.550 \\
\hline Italy & 0.028 & 0.080 & 0.080 & -0.001 & 0.117 & 0.038 & 0.042 & 0.079 & 0.068 & 0.026 & 0.099 & 0.117 & 0.777 \\
\hline Jamaica & 0.001 & 0.077 & 0.084 & 0.028 & 0.109 & 0.001 & 0.000 & 0.001 & 0.086 & 0.001 & 0.037 & 0.001 & 0.371 \\
\hline Japan & 0.054 & 0.097 & 0.111 & -0.001 & 0.111 & 0.340 & 0.177 & 0.211 & 0.094 & 0.067 & 0.214 & 0.176 & 1.653 \\
\hline Kazakhstan & 0.026 & 0.114 & 0.086 & 0.172 & 0.097 & 0.008 & 0.001 & 0.006 & 0.109 & 0.009 & 0.039 & 0.007 & 0.330 \\
\hline Kenya & 0.001 & 0.064 & 0.049 & 0.075 & 0.072 & 0.002 & 0.001 & 0.003 & 0.069 & 0.019 & 0.038 & 0.004 & 0.247 \\
\hline Kuwait & 0.000 & 0.163 & 0.105 & 0.038 & 0.081 & 0.009 & 0.000 & 0.005 & 0.108 & 0.002 & 0.120 & 0.009 & 0.565 \\
\hline
\end{tabular}


Appendix 1. Result of MOORA Method (Continued)

\begin{tabular}{|c|c|c|c|c|c|c|c|c|c|c|c|c|c|}
\hline Normalization & $\max$ & $\max$ & $\max$ & $\min$ & $\max$ & $\max$ & $\max$ & $\max$ & $\max$ & $\max$ & $\max$ & $\max$ & \\
\hline Alternatives & $C 1$ & $C 2$ & C3 & C4 & C5 & C6 & $C 7$ & $C 8$ & $C 9$ & C10 & C11 & C12 & $y^{*}$ \\
\hline Latvia & 0.000 & 0.072 & 0.086 & 0.002 & 0.118 & 0.001 & 0.000 & 0.001 & 0.079 & 0.001 & 0.078 & 0.004 & 0.439 \\
\hline Lebanon & 0.004 & 0.056 & 031 & -0.010 & 0.126 & 0.015 & 0.000 & 0.002 & 0.100 & 0.002 & 0.124 & 0.005 & 0.476 \\
\hline Lithuania & 0.001 & 0.097 & 0.067 & 0.011 & 0.107 & 0.001 & 0.001 & 0.002 & 0.069 & 0.001 & 0.050 & 0.008 & 0.393 \\
\hline Luxembourg & 0.041 & 0.043 & 0.088 & 0.004 & 0.137 & 0.000 & 0.032 & 0.003 & 0.072 & 0.000 & 0.119 & 0.006 & 0.539 \\
\hline Malaysia & 0.021 & 0.129 & 0.115 & 0.025 & 0.084 & 0.026 & 0.012 & 0.013 & 0.104 & 0.015 & 0.144 & 0.049 & 0.686 \\
\hline Malta & 0.004 & 0.049 & 0.127 & 0.007 & 0.133 & 0.000 & 0.004 & 0.000 & 0.095 & 0.000 & 0.101 & 0.002 & 0.508 \\
\hline Mexico & 0.052 & 0.110 & 0.095 & 0.033 & 0.100 & 0.050 & 0.002 & 0.045 & 0.093 & 0.057 & 0.041 & 0.115 & 0.728 \\
\hline Mongolia & -0.006 & 0.124 & 0.119 & 0.007 & 0.080 & 0.000 & 0.000 & 0.000 & 0.118 & 0.001 & 0.068 & 0.001 & 0.499 \\
\hline Morocco & 0.004 & 0.099 & 0.118 & 0.019 & 0.090 & 0.007 & 0.001 & 0.004 & 0.133 & 0.013 & 0.074 & 0.012 & 0.535 \\
\hline Netherlands & 0.237 & 0.067 & 0.118 & 0.004 & 0.124 & 0.010 & 0.434 & 0.033 & 0.080 & 0.009 & 0.128 & 0.146 & 1.383 \\
\hline New Zealand & 0.003 & 0.073 & 0.080 & 0.013 & 0.113 & 0.005 & 0.007 & 0.008 & 0.093 & 0.003 & 0.082 & 0.010 & 0.465 \\
\hline Nicaragua & 0.001 & 0.090 & 0.103 & 0.042 & 0.088 & 0.001 & 0.000 & 0.001 & 0.125 & 0.003 & 0.045 & 0.002 & 0.417 \\
\hline Nigeria & 0.007 & 0.062 & 0.070 & 0.186 & 0.095 & 0.008 & 0.002 & 0.017 & 0.062 & 0.058 & 0.018 & 0.011 & 0.226 \\
\hline Norway & -0.025 & 0.108 & 0.137 & 0.042 & 0.104 & 0.017 & 0.005 & 0.016 & 0.118 & 0.003 & 0.168 & 0.021 & 0.628 \\
\hline Oman & 0.003 & 0.160 & 0.104 & 0.013 & 0.080 & 0.006 & 0.000 & 0.003 & 0.144 & 0.002 & 0.088 & 0.007 & 0.582 \\
\hline Pakistan & 0.004 & 0.065 & 0.094 & 0.044 & 0.088 & 0.006 & 0.002 & 0.012 & 0.062 & 0.069 & 0.019 & 0.014 & 0.391 \\
\hline Panama & 0.009 & 0.095 & 0.131 & 0.009 & 0.109 & 0.001 & 0.000 & 0.002 & 0.185 & 0.002 & 0.106 & 0.005 & 0.637 \\
\hline Paraguay & 0.001 & 0.102 & 0.072 & 0.048 & 0.079 & 0.002 & 0.000 & 0.001 & 0.072 & 0.003 & 0.063 & 0.003 & 0.349 \\
\hline Peru & 0.011 & 0.109 & 0.080 & 0.043 & 0.095 & 0.017 & 0.003 & 0.008 & 0.087 & 0.018 & 0.042 & 0.011 & 0.438 \\
\hline Philippin & 0. & 0 & 0.179 & 0.021 & 0.094 & 0.023 & 0.005 & 0.013 & 0.097 & 0.044 & 0.052 & .025 & 627 \\
\hline Poland & 0.026 & 0.113 & 0.079 & -0.007 & 0.100 & 0.032 & 0.024 & 0.020 & 0.079 & 0.019 & 0.063 & 0.057 & 0.620 \\
\hline Portugal & 0.014 & 0.075 & 0.062 & 0.007 & 0.119 & 0.007 & 0.007 & 0.009 & 0.062 & 0.005 & 0.130 & 0.020 & 0.503 \\
\hline Qatar & 0.001 & 0.175 & 0.190 & 0.034 & 0.075 & 0.009 & 0.000 & 0.007 & 0.181 & 0.002 & 0.092 & 0.009 & 0.707 \\
\hline Romania & 0.008 & 0.109 & 0.092 & -0.018 & 0.100 & 0.011 & 0.007 & 0.008 & 0.100 & 0.009 & 0.033 & 0.022 & 0.518 \\
\hline & & & & & & & & 55 & & 77 & 062 & 056 & 72 \\
\hline Rwanda & 0.000 & 0.059 & 0.048 & 0.068 & 0.080 & 0.000 & 0.000 & 0.000 & 0.105 & 0.006 & 0.025 & 0.001 & 0.257 \\
\hline Saudi Arab & 0.011 & 0.146 & 0.111 & 0.042 & 0.085 & 0.153 & 0.000 & 0.028 & 0.124 & 0.014 & 0.067 & 0.039 & 0.737 \\
\hline Serbia & 0.004 & 0.105 & 0.062 & 0.013 & 0.096 & 0.003 & 0.002 & 0.002 & 0.077 & 0.003 & 0.050 & 0.006 & 0.396 \\
\hline Singapore & 0.095 & 0.088 & 0.181 & -0.006 & 0.117 & 0.070 & 0.174 & 0.013 & 0.102 & 0.003 & 0.154 & 0.085 & 1.087 \\
\hline Slovak Rep. & 005 & 117 & 0.089 & -0.006 & 097 & 0.001 & 005 & 004 & 0.091 & 003 & 066 & .022 & 0.506 \\
\hline Slovenia & 0.002 & 0.109 & 0.098 & -0.001 & 0.104 & 0.000 & 0.002 & 0.002 & 0.075 & 0.001 & 0.054 & 0.009 & 0.456 \\
\hline South Africa & 0.003 & 0.097 & 0.066 & 0.075 & 0.108 & 0.013 & 0.018 & 0.013 & 0.078 & 0.022 & 0.168 & 0.027 & 0.538 \\
\hline Spain & 0.049 & 0.079 & 0.091 & -0.002 & 0.117 & 0.018 & 0.045 & 0.053 & 0.082 & 0.023 & 0.129 & 0.090 & 0.779 \\
\hline Sri Lanka & 0.001 & 0.100 & 0.118 & 0.047 & 0.098 & 0.002 & 0.000 & 0.003 & 0.126 & 0.009 & 0.053 & 0.006 & 0.469 \\
\hline Suriname & 0.000 & 0.108 & 0.256 & 0.619 & 0.092 & 0.000 & 0.000 & 0.000 & 0.265 & 0.000 & 0.043 & 0.000 & 0.145 \\
\hline Sweden & 0.024 & 0.083 & 0.119 & 0.012 & 0.117 & 0.017 & 0.028 & 0.022 & 0.099 & 0.005 & 0.149 & 0.041 & 0.693 \\
\hline Switzerland & -0.027 & 0.087 & 0.133 & -0.005 & 0.116 & 0.190 & 0.109 & 0.029 & 0.093 & 0.005 & 0.203 & 0.078 & 1.021 \\
\hline Thailand & 0.005 & 0.121 & 0.136 & 0.002 & 0.088 & 0.048 & 0.036 & 0.017 & 0.088 & 0.039 & 0.171 & 0.056 & 0.803 \\
\hline Turkey & 0.019 & 0.108 & 0.100 & 0.092 & 0.096 & 0.030 & 0.007 & 0.037 & 0.113 & 0.031 & 0.081 & 0.058 & 0.587 \\
\hline Uganda & 0.001 & 0.076 & 0.079 & 0.065 & 0.082 & 0.001 & 0.000 & 0.001 & 0.102 & 0.015 & 0.018 & 0.001 & 0.312 \\
\hline Ukraine & 0.005 & 0.091 & 0.071 & 0.164 & 0.093 & 0.004 & 0.003 & 0.004 & 0.086 & 0.021 & 0.055 & 0.011 & 0.282 \\
\hline U.Arab Emirates & 0.014 & 0.136 & 0.092 & 0.019 & 0.093 & 0.024 & 0.000 & 0.015 & 0.101 & 0.006 & 0.100 & 0.065 & 0.627 \\
\hline United Kingdom & 0.451 & 0.068 & 0.046 & 0.008 & 0.125 & 0.038 & 0.108 & 0.113 & 0.068 & 0.034 & 0.156 & 0.184 & 1.383 \\
\hline United States & 0.737 & 0.067 & 0.074 & 0.015 & 0.125 & 0.114 & 0.400 & 0.795 & 0.079 & 0.164 & 0.223 & 0.652 & 3.416 \\
\hline Uruguay & 0.000 & 0.097 & 0.072 & 0.114 & 0.102 & 0.004 & 0.001 & 0.002 & 0.075 & 0.002 & 0.033 & 0.002 & 0.275 \\
\hline Vietnam & 0.019 & 0.122 & 0.118 & 0.038 & 0.072 & 0.010 & 0.000 & 0.009 & 0.107 & 0.056 & 0.144 & 0.050 & 0.669 \\
\hline Zambia & 0.002 & 0.123 & 0.137 & 0.212 & 0.090 & 0.001 & 0.000 & 0.001 & 0.152 & 0.007 & 0.014 & 0.002 & 0.318 \\
\hline
\end{tabular}

